\title{
Neuropilins and Their Ligands Are Important in the Migration of Gonadotropin-Releasing Hormone Neurons
}

\author{
Anna Cariboni, ${ }^{1,3}$ Jason Hickok, ${ }^{2}$ Sonja Rakic, ${ }^{1}$ William Andrews, ${ }^{1}$ Roberto Maggi, ${ }^{3}$ Shelley Tischkau, ${ }^{2}$ and \\ John G. Parnavelas ${ }^{1}$ \\ ${ }^{1}$ Department of Anatomy and Developmental Biology, University College London, London WC1E 6BT, United Kingdom, ${ }^{2}$ Department of Veterinary \\ Biosciences, University of Illinois at Urbana-Champaign, Urbana, Illinois 61801, and ${ }^{3}$ Department of Endocrinology, University of Milan, 20133 Milan, Italy
}

\begin{abstract}
Gonadotropin-releasing hormone ( $\mathrm{GnRH}$ ) neurons in the hypothalamus play an important role in reproductive function. These cells originate in the nasal compartment and migrate into the basal forebrain in association with olfactory/vomeronasal nerves in embryonic life in rodents. Here, we studied the role of neuropilins and their ligands, semaphorins, in the development of the olfactory-GnRH system. We focused on Neuropilin-2 knock-out $\left(\mathrm{Npn-2^{-/ }}\right)$ mice, because they are known to display defasciculation of olfactory nerves and reduced fertility. We found a significant decrease in the number of $\mathrm{GnRH}$ neurons in the hypothalamus and a marked reduction in their

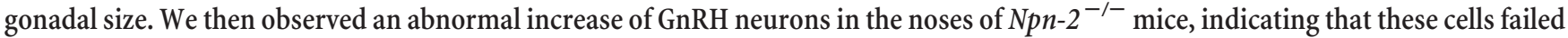
to migrate into the forebrain. However, because neuropilins and semaphorins are involved in events of neuronal migration in the brain, we asked whether the observed reduction in GnRH neurons was directly attributable to the action of these molecules. Using fluorescenceactivated cell sorting and reverse transcription-PCR on mRNA derived from embryonic green fluorescent protein (GFP)-GnRH transgenic mice, we found expression of class 3 semaphorins and their receptors (neuropilin-1/2 and plexin-A1) in GnRH neurons. Furthermore, double-immunofluorescence experiments showed that migrating GnRH neurons, as well as associated olfactory fibers, express Npn-2 in the nasal region. We then used a line of immortalized GnRH neurons (GN11 cells) that display the same expression patterns for semaphorins and their receptors as GFP-GnRH cells and found that class 3 semaphorins and vascular endothelial growth factors modulate their migratory activity. These studies provide support for the direct involvement of neuropilins and their ligands in the establishment of the GnRH neuroendocrine system.
\end{abstract}

Key words: GnRH neurons; hypothalamus; migration; neuropilin; reproduction; semaphorin

\section{Introduction}

The reproductive behavior in mammals is centrally regulated by a small number of gonadotropin-releasing hormone (GnRH)secreting neurons located in the hypothalamus. These cells project to the median eminence, where they secrete the decapeptide into the pituitary portal vessels to induce the release of gonadotropins from the pituitary gland into the general circulation (Merchenthaler et al., 1984; Barry et al., 1985). During embryogenesis, GnRH neurons originate in the nasal compartment and migrate in association with olfactory nerves (vomeronasal and terminal) to enter into the forebrain and reach their final destinations (Schwanzel-Fukuda and Pfaff, 1989; Wray et al., 1989). Defects in the migration of these neurons in humans result in infertility (Hardelin, 2001; MacColl et al., 2002).

\footnotetext{
Received July 31, 2006; revised Jan. 25, 2007; accepted Jan. 27, 2007.

This work was supported by Wellcome Trust Programme Grant 074549 (J.G.P.), by Progetti di Ricerca di Interesse Nazionale 2005 Grant 2005051740 (R.M.), by National Institutes of Health Grant ES012948 and the Illinois Governor's Venture Technology Fund (S.T.), and by The Billie's Field's Graduate Fellowship (J.H.). We thank Dr. Barbara Pilas for help with FACS sorting, Mary Antypa for help in different phases of the work, and Dr. Mario Milani for his contribution to the histological analysis of the testes.

Correspondence should be addressed to John G. Parnavelas, Department of Anatomy and Developmental Biology, University College London, Gower Street, London WC1E 6BT, UK. E-mail: j.parnavelas@ucl.ac.uk.

D0I:10.1523/JNEUROSC1.5075-06.2007

Copyright $\odot 2007$ Society for Neuroscience $\quad$ 0270-6474/07/272387-09\$15.00/0
}

The mechanisms underlying the establishment of the migration route and the movement of GnRH neurons are thought to involve different classes of molecules (for review, see Tobet and Schwarting, 2006). Candidates include semaphorins and their receptors, because of their high levels of expression in the developing olfactory system (Wray, 2001). Semaphorins are a family of secreted or cell-bound molecules that modulate axonal guidance and neuronal migration events in the developing nervous system [for review, see Tamagnone and Comoglio (2004) and Kruger et al. (2005)]. The secreted class 3 semaphorins exert their actions by binding neuropilins (Npn-1 and Npn-2) (Kolodkin et al., 1997; Tamagnone et al., 1999) and plexins (Winberg et al., 1998; Takahashi et al., 1999). In addition to binding secreted semaphorins, neuropilins are coreceptors for vascular endothelial growth factors (VEGFs) (Soker et al., 1998; Gluzman-Poltorak et al., 2000, 2001; Karpanen et al., 2006), molecules actively involved in vascular development and recently shown to have roles in neuronal migration (Schwarz et al., 2004).

Two class 3 semaphorins, Sema3A and Sema3F, are expressed in the developing olfactory system: specifically, Sema3A is expressed in the olfactory epithelium, whereas Sema3F is mainly expressed in the vomeronasal organ (VNO) and in the medial part of the olfactory bulb (Cloutier et al., 2002). Their specific coreceptors, Npn-1 and Npn-2, are expressed on sensory neu- 
rons in the main and accessory olfactory epithelia, respectively (Giger et al., 1996, 2000; Cloutier et al., 2002). Concomitantly, members of the plexin-A subfamily are expressed in the olfactory system, with robust expression of plexin-A1 (Plxna1) in the VNO and vomeronasal nerves (VNNs) (Murakami et al., 2001). Loss of Sema3A results in guidance errors in subsets of olfactory axons (Schwarting et al., 2000; Taniguchi et al., 2003), whereas loss of Sema3F or Npn-2 functions results in defasciculation of the VNNs along the medial surface of the olfactory bulb (Cloutier et al., 2002, 2004; Walz et al., 2002). Moreover, it has been reported that $N p n-2^{-1-}$ mice are often infertile (Giger et al., 2000; Walz et al., 2002), prompting us to investigate the role of Npn-2 in the development and migration of GnRH neurons.

Using different experimental approaches, we found a direct role for Npn-2 and its ligands on the migration of GnRH neurons. Specifically, newborn $N p n-2^{-1-}$ mice contained significantly fewer GnRH neurons in the forebrain and abnormal excess of these cells in the nose, indicating a defect in their migration at this level. Furthermore, adult males showed genitalia of considerably smaller size and altered histology, thus providing an explanation for their reduced fertility. Using fluorescence activated cell sorting and reverse transcription (RT)-PCR on mRNA derived from green fluorescent protein (GFP)-GnRH transgenic mice, we also found expression of neuropilins and their ligands in GnRH neurons. Moreover, using immortalized GnRH cells, we showed that semaphorins and VEGFs affect the migratory activity of these cells, strongly supporting a direct involvement for these molecules in the establishment of the GnRH neuroendocrine system.

\section{Materials and Methods}

Animals. All animal procedures were performed in accordance with institutional guidelines. The line of $\mathrm{Npn}-2^{-/-}$mice was established from breeding pairs of animals obtained from Dr. S. McMahon (Kings College London, London, UK) (Giger et al., 2000). Heads of embryos, removed from pregnant transgenic GFP-GnRH mice (provided by S.T.) at different stages of gestation [embryonic day 0 (E0) is the day the vaginal plug was found] and from pregnant C57BL/6J mice, were used for RT-PCR and immunofluorescence experiments, respectively.

Cell lines. GN11 cells, generously provided to R.M. by Dr. S. Radovick (University of Chicago, Chicago, IL), and COS-7 cells (American Type Culture Collection, Manassas, VA) were grown as a monolayer at $37^{\circ} \mathrm{C}$ in a humidified $\mathrm{CO}_{2}$ incubator in complete DMEM (Biochrom, Berlin, Germany) and supplemented with $10 \%$ fetal bovine serum (FBS; Invitrogen, Carlsbad, CA). Subconfluent cells were harvested by trypsinization and cultured in $57 \mathrm{~cm}^{2}$ dishes. Cells within six passages were used in all experiments.

Production of semaphorin-conditioned media. Full-length chicken semaphorin $3 A-m y c$ cDNA plasmid, encoding for $\mathrm{N}$-terminal tagged c-myc semaphorin3A, was kindly provided by Dr. H. Schmidt (Max Delbrück Center, Berlin, Germany); pMT21-myc plasmid was chosen as a control. FLAG-tagged mouse Sema3F was created by inserting mouse semaphorin $3 F$, derived by PCR using Pfu polymerase and pcDNA1.1amp-mouse-semaphorin3F plasmid as a template (a gift from Dr. H. Schmidt), into vector p3xFLAG-CMV-8 (Sigma, Poole, UK). The mouse semaphorin $3 F$ was obtained using the forward primer CTGAGCGGCCGCGAACTGGAGCCTGCTT and the reverse primer CTGATCTAGATAGGCTGGTCCTATGCAG, which incorporated NotI and $\mathrm{XbaI}$ sites, respectively. The insert was ligated into the p3xFLAGCMV-8 vector in frame between NotI and XbaI sites, and the plasmid was verified by sequencing, transfection of cells, and Western blot analysis (supplemental figure, available at www.jneurosci.org as supplemental material); p3xFLAG-CMV-8 was chosen as a control plasmid. For transfection, COS-7 cells (at 80\% confluence) were grown in culture plates in complete culture medium for $24 \mathrm{~h}$ and incubated for $3 \mathrm{~h}$ with the selected expression vector $(1 \mu \mathrm{g} / \mathrm{ml})$ in the presence of Lipofectamine 2000 (In- vitrogen) according to the manufacturer's instructions. Conditioned media from semaphorin $3 A-m y c$ plasmid- (CM-sema3A), semaphorin $3 F-$ FLAG plasmid- (CM-sema3F), pMT21-myc (CM-myc)-, and p3xFLAGCMV-8 (CM-FLAG)-transfected COS-7 cells were obtained by leaving transfected COS-7 cells in serum-free medium for $24 \mathrm{~h}$. Cell supernatants were collected in ice-cold tubes, centrifuged at $3000 \times g$ for $5 \mathrm{~min}$ and immediately used for microchemotaxis assays. Production and secretion of semaphorin $3 \mathrm{~A}$ and semaphorin3F were confirmed by immunofluorescence and Western blot analysis on cell extracts and conditioned media using monoclonal anti-c-myc (1:500; clone 9E10; Sigma) and antiFLAG (1:500; clone M2; Sigma) antibodies (supplemental figure, available at www.jneurosci.org as supplemental material).

Collagen gel cocultures. Cell aggregates of GN11 cells were prepared by the "hanging drop" technique as described previously (Kennedy et al., 1994). Rat-tail collagen solution was prepared as described by Guthrie and Lumsden (1994), and collagen gels and GN11 cell aggregates were generated as described by Cariboni et al. (2005). After collagen polymerization (30 min), the preparations were covered with $500 \mu \mathrm{l}$ of control or semaphorin-enriched $\mathrm{CM}$ and cultured in a humidified, $5 \% \mathrm{CO}_{2}, 37^{\circ} \mathrm{C}$ incubator. After $24 \mathrm{~h}$ in culture, GN11 cell aggregates were fixed in $4 \%$ paraformaldehyde and immunostained with phalloidin-tetramethylrhodamine isothiocyanate (1:500; overnight in PBS plus $0.3 \%$ Triton X-100; Sigma). Representative images for each treatment were taken with a DM5000B microscope (Leica Microsystems, Milton Keynes, UK).

Chemomigration assays. Chemomigration assays were performed using a 48-well Boyden's chamber as described previously (Maggi et al., 2000; Cariboni et al., 2005). Different semaphorin CMs or control CM and recombinant VEGF forms [50 nM; mouse VEGF ${ }^{164}$ (R \& D Systems, Abingdon, UK) and rat VEGF-C (ReliaTech, Braunschweig, Germany)] were used as chemoattractants and placed into the lower compartment of the chamber. The chamber was kept in an incubator at $37^{\circ} \mathrm{C}$ for $3 \mathrm{~h}$. After this time, the migrated cells were fixed and stained using the Diff-Quick kit (Biomap, Milan, Italy). For quantitative analysis, the membranes were observed using an Olympus (Tokyo, Japan) light microscope with a $20 \times$ objective. Three random fields of stained cells were counted for each well, and the mean number of migrating cells $/ \mathrm{mm}^{2}$ for each experimental condition was calculated. Statistical analysis was performed using Prism4 software (GraphPad Software, San Diego, CA).

Immunofluorescence. GN11 cells were fixed in $100 \% \mathrm{MetOH}$ at $-20^{\circ} \mathrm{C}$ for 20 min, blocked with $10 \%$ BSA in PBS at room temperature for $1 \mathrm{~h}$, and stained overnight with polyclonal anti-Npn-1 (1:50; Merck Biosciences, Nottingham, UK), Npn-2 (1:50; H300; Santa Cruz Biotechnology, Santa Cruz, CA) or plexin-A1 (1:50; H60; Santa Cruz Biotechnology) antibodies, followed by incubation with a goat anti-rabbit Alexa Fluor 488 (1:400; Invitrogen) at room temperature for $1 \mathrm{~h}$. Nuclei were counterstained with $4^{\prime}, 6^{\prime}$-diamidino-2-phenylindole dihydrochloride (DAPI). Fresh-frozen heads from embryonic mice were cut with a cryostat at $15 \mu \mathrm{m}$. Sections were blocked with $10 \%$ NGS in PBS/0.3\% Triton $\mathrm{X}-100$ for $1 \mathrm{~h}$ and then incubated in monoclonal anti-peripherin (1:1000; Millipore, Billerica, MA) or polyclonal anti-Npn-1, Npn-2 (1:50), or GnRH (1:400; ImmunoStar, Hudson, WI) antibodies at room temperature overnight, followed by Alexa Fluor 568 anti-mouse IgG or Alexa Fluor 488 anti-rabbit IgG (Invitrogen). Nuclei were counterstained with DAPI (Sigma). When two polyclonal primary antibodies were used (anti$\mathrm{GnRH} / \mathrm{Npn}-2)$, staining of the first antigen-antibody complex $(\mathrm{GnRH})$ was visualized with a goat anti-rabbit Alexa Fluor 488 (1:400; Invitrogen) secondary antibody (Giacobini et al., 2004). This was followed by a blocking reaction with $10 \%$ normal rabbit serum (Sigma) at room temperature for $1 \mathrm{~h}$, followed by washes in PBS plus $0.1 \%$ Triton X-100 and fixation ( $4 \%$ paraformaldehyde for $45 \mathrm{~min}$ ), before application of the second primary antibody, which was visualized with goat anti-rabbit Alexa Fluor 594 (1:400; Invitrogen). Preparations were then examined with a confocal microscope (Leica Microsystems), and images were reconstructed using MetaMorph imaging software (Universal Imaging, West Chester, PA).

Analysis of $\mathrm{Npn}-2^{-1-}$ mice. Litters containing $\mathrm{Npn}-2^{-1-}$ mice were genotyped using two specific polymerase chain reactions. Forward primer NPN-2F (5'-CTCGGTCACAAGCTGGCTTG-3') and either NPN-2RevWT (5'-ACCTTTGCAGAAGACACCACCAGGAGG-3') or 
Table 1. Sequences $\left(5^{\prime}-3^{\prime}\right)$, amplicon length, and accession numbers of primers

\begin{tabular}{|c|c|c|c|}
\hline Primer & Sequence & Amplicon & Accession number \\
\hline Sema3AF & CGGACTTCATGGGACGGGAC & 330 & BC057588 \\
\hline Sema3AR & GCCCGGTCCC AATGGCATTG & & \\
\hline Sema $3 A F^{n}$ & GGACGGAGCAGCATGACTCC & 190 & \\
\hline Sema3A $R^{n}$ & TGCAAGAATG ACTTTGGTGG & & \\
\hline Sema3FF & TGTACATCGATTTTATGGGTACCGA & 262 & NM_011349 \\
\hline Sema3F R & TCAACGATGACGGTGGCCATTGCTG & & \\
\hline Sema3F $F^{n}$ & GCCATGCGCACAGATCAG & 110 & \\
\hline Sema3F R ${ }^{n}$ & ATGACGATAA ACTCTACTTC & & \\
\hline Npn-1F & TTCCGCAGCGACAAATGTGG & 190 & NM_008737 \\
\hline Npn-1 R & GAGGACAGAGACTGCAAGTA & & \\
\hline Npn-1 $F^{n}$ & CGGGACCATA AAAATCGAAA & 140 & \\
\hline Npn-1 $R^{n}$ & AATCAACTTC AACCCACATT & & \\
\hline Npn-2 F & CGAATTCCAA AGATGCTGGC & 260 & NM_010939 \\
\hline Npn-2 R & ССАTСATCTC CTCAGGCTCC & & \\
\hline Npn-2 $F^{n}$ & ACCAGAACTG TGAGTGGATT & 110 & \\
\hline Npn-2 $R^{n}$ & ACTGCAAGTA TGACTTCATT & & \\
\hline Plexin-A1 F & TGCATCAACT CGCCCCTGCAG & 199 & NM_008881 \\
\hline Plexin-A1 R & GGCCGCATCC GCAAGATTCT & & \\
\hline Plexin-A1 F ${ }^{n}$ & ACGACTTCTGCGGGCAGGATTTCAA & 132 & \\
\hline Plexin-A1 R & ACTACCAAGGCCGCACCGTGG & & \\
\hline
\end{tabular}

$F$, Forward; $R$, reverse; $F^{n}$, forward nested; $R^{n}$, reverse nested.

NPN-2RevMUT (5'-GAGCGCGCGCGGCGGAGTTGTTGAC) were used to detect either the wild-type (WT) or knock-out allele, respectively. Brains and noses were removed from the heads of newborn animals, fixed with $4 \%$ paraformaldehyde overnight, embedded in 3.5\% agarose, and cut sagittally at $100 \mu \mathrm{m}$ using a Vibroslice (VT1000S; Leica Microsystems). Free-floating sections were blocked with 10\% NGS in PBS/ $0.3 \%$ Triton X-100 at room temperature for $1 \mathrm{~h}$, incubated in $\mathrm{GnRH}$ antibody (1:4000; ImmunoStar) for $48 \mathrm{~h}$, followed by an anti-rabbit biotinylated secondary antibody, and processed using an ABC kit (Vector Laboratories, Burlingame, CA) with 3,3-diaminobenzidine $(0.015 \%$; Sigma) as a chromogen. Sections were then washed in PBS, mounted on slides, dehydrated, and coverslipped. All GnRH neurons identified in all sections were counted, and statistical analysis was performed using Prism4 software (GraphPad Software). For histology of the gonads, the testes of $N p n-2^{-/-}$and wild-type mice ( $n=3$ for each genotype), perfused with $4 \%$ paraformaldehyde, were embedded in optimal cutting temperature medium and serially sectioned with a cryostat at $10 \mu \mathrm{m}$. Sections were stained with hematoxylin and eosin.

Fluorescence-activated cell sorter analysis. Small pieces of tissue were microdissected from heads of GFP-GnRH embryos and pooled in a 1.5 $\mathrm{ml}$ Microfuge tube containing $980 \mu \mathrm{l}$ of HBSS preheated to $37^{\circ} \mathrm{C}$. Liberase Blendzyme 3 (Roche Applied Science, Indianapolis, IN) was added at a final concentration of $0.14 \mathrm{U} / \mathrm{ml}$, and the suspension was incubated at $37^{\circ} \mathrm{C}$ for $3 \mathrm{~min}$. A single-cell suspension was obtained by gently pipetting the sample with Pasteur pipettes of increasingly smaller diameter. Once the sample no longer contained any visible clumps of tissue, it was filtered through a $35 \mu \mathrm{m}$ filter (BD Biosciences, San Jose, CA) and centrifuged $(1000 \mathrm{rpm})$ at $4^{\circ} \mathrm{C}$ for $5 \mathrm{~min}$. Supernatant was aspirated, and the pellet was diluted with $500 \mu \mathrm{l}$ of RNAlater solution (RNA aqueous Micro Kit; Ambion, Austin, TX) to preserve the RNA. Samples were resuspended in $500 \mu \mathrm{l}$ of PBS before being placed in a fluorescence-activated cell sorter (FACS). Sorted (top 1\% of GFP-positive cells) and unsorted (GFP-negative) cells were collected into two different tubes, each containing $500 \mu \mathrm{l}$ of lysis buffer (Ambion), and used for RNA extraction. The sorted population was GnRH positive, as demonstrated by RT-PCR (data not shown). RT-PCR was performed on these samples as described below using the same set of primers implemented in the experiments with GN11 cells.

$R T-P C R$. Total RNA from GN11 cells was isolated by extraction with TRIzol (Invitrogen). For samples derived from GFP-GnRH mice, RNA extraction was performed using the RNA aqueous Micro kit (Ambion). The amount of RNA obtained was in the range of 20-50 ng, because of the relatively small number of GFP-GnRH cells collected from the sorter. Single-strand cDNA was synthesized by avian myeloblastosis virus re- verse transcriptase (Promega, Southampton, UK) and random hexamers (Promega). PCR was performed using $0.5 \mu \mathrm{l}$ of cDNA and the appropriate oligonucleotides $(0.6-6 \mu \mathrm{M})$ in 25 $\mu \mathrm{l}$ of reaction mix using TaqDNA polymerase (Qiagen, Crawley, UK) and the following conditions: 35 cycles of denaturing at $94^{\circ} \mathrm{C}$ for $60 \mathrm{~s}$, annealing at $60^{\circ} \mathrm{C}$ for $60 \mathrm{~s}$, and extension at $72^{\circ} \mathrm{C}$ for $120 \mathrm{~s}$. PCR products were analyzed by electrophoresis on a $2 \%$ agarose gel, and bands were visualized under UV illumination after ethidium bromide staining. The primers used are listed in Table 1.

\section{Results \\ $\mathrm{Npn}-2^{-/-}$mice show a reduction in GnRH neurons}

Previous studies (Giger et al., 2000; Walz et al., 2002) have reported that homozygous $N p n-2^{-1-}$ mice are often unable to reproduce. We first investigated whether this was attributable to a defect in the number or position of GnRH neurons in the brains of newborn and adult animals. In these immunohistochemical experiments, we cut sagittal sections through the entire brains, stained all sections with an anti-GnRH antibody, and counted all labeled cells. Analysis showed that the brains of P0 Npn-2 $2^{-/-}$mice $(n=$ $5)$ contained significantly fewer $(p<0.05)$ GnRH neurons dispersed in the olfactory bulb and ventral forebrain (525.2 \pm 18.69 ; mean \pm SEM) compared with WT littermates $(725.0 \pm 26.62)$. Moreover, whereas in WT mice, many GnRH-positive fibers in the hypothalamus were seen to project to the median eminence (Fig. 1c), the density of these fibers was notably reduced in Npn$2^{-/-}$animals (Fig. $1 d$ ). No difference in the migration pathway was observed within the brains of $N p n-2^{-/-}$, suggesting a problem of migration in the nasal area. In fact, immunostaining of coronal sections taken from the noses of newborn $\mathrm{Npn-2^{-/- }}$ mice showed an increased presence of GnRH-positive neurons along the nasal septum (Fig. $1 b$, arrowheads), often appearing as clusters, suggesting an arrest or delay in the migration of $\mathrm{GnRH}$ neurons. Counts of labeled cells confirmed this observation; there were, on average, more than twice as many $(p<0.05)$ GnRH neurons along the nasal septum of $N p n-2^{-/-}$animals $(273.3 \pm 16.2 ; n=$ $3)$ as in WT littermates $(125.3 \pm 2.9 ; n=3)$. Cells were counted in all sections obtained from the entire nasal region (i.e., from the tip of the nose to the start of the olfactory bulb).

To investigate whether the reduction in the number of $\mathrm{GnRH}$ neurons is reflected in alterations in the gonads, we examined the testes of adult ( 3 months of age; $n=3$ ) male Npn-2 $2^{-/-}$and WT littermates. Visual inspection and measurements indicated a significant reduction in the dimensions of the testes of $\mathrm{Npn-2^{-/- }}$ animals (long axis, $6.125 \pm 0.125 \mathrm{~mm}$ ) compared with WT $(8.25 \pm 0.43 \mathrm{~mm})$ (Fig. 1d). Abnormalities of testicular morphology in $N p n-2^{-/-}$mice were also apparent in hematoxylin- and eosin-stained sections (Fig. $1 f, g$ ). In these mice, the size of the seminiferous tubules appeared reduced compared with WT. In addition, the tubules showed smaller lumens with a reduced number of spermatozoa and an accumulation of spermatogenic immature cells. No hyperplasia of Leydig's cells was seen, substantiating a central defect in the reproductive axis. Counts of all GnRH-positive neurons present in the brains of these adult mice confirmed the numeric reduction observed in newborn animals, 
with $490.7 \pm 32.92$ in the $N p n-2^{-1-}$ mice and $645 \pm 4.177$ in the WT $(n=3)$.

We then used immunofluorescence to stain the nasal regions of embryonic (E15) $N p n-2^{-/-}$and WT animals with peripherin, a specific marker of olfactory axons that are associated with migrating $\mathrm{GnRH}$ neurons. In accordance with previous reports (Cloutier et al., 2002; Walz et al., 2002), we observed defasciculation of these axonal tracts and improper innervation of the olfactory bulb in $N p n-2^{-/-}$animals compared with WT littermates (Fig. 2). We reasoned that defects in fasciculation of the VNN would hamper the migration of GnRH neurons along it and would explain the reduced number observed in the brains of $\mathrm{Npn}-2^{-/-}$mice. However, a direct role for neuropilins and their ligands in the migration of the GnRH neurons cannot be excluded. To address this point, additional experiments were performed using different experimental approaches.

\section{Expression of semaphorins and neuropilins in GnRH neurons}

We first examined the expression pattern of semaphorins and their receptors in $\mathrm{GnRH}$ neurons. We took advantage of a mouse model in which the GFP reporter was genetically targeted to $\mathrm{GnRH}$ neurons. In these mice, nearly all (>99.5\%) GFP-expressing neurons contain immunologically detectable $\mathrm{GnRH}$ peptide (Suter et al., 2000). Using FACS analysis (Fig. 3a), we isolated GFP-positive cells from the heads of embryos at different gestational stages (E13.5, E15, and E17) and extracted mRNA. We then applied RT-PCR and found transcripts of expected molecular sizes for mouse Sema3A, Sema3F, Npn-1, Npn-2, and Plxna1 in these cells (Fig. $3 b$ ). Nested PCR with a second set of primers (Table 1) confirmed the specificity of the first-round reaction (data not shown). The same samples were also tested for the presence of GnRH mRNA and found positive (data not shown). These results indicated that GnRH-GFP cells express both ligands (Sema3A and Sema3F) and receptors/coreceptors (Plxna1, Npn-1, and Npn-2), supporting a direct role for these molecules in the development of $\mathrm{GnRH}$ neurons.

We then studied the localization of the appropriate neuropilin and plexin receptors in the nasal compartment of rodents, the start of the migratory pathway of GnRH neurons. We first showed that olfactory fibers, used by GnRH neurons to migrate from the olfactory placode toward the olfactory bulb (Fig. $3 c$ ), are strongly labeled for Npn-2 (Fig. 3d) and faintly stained for Npn-1 (data not shown). Available plexin-A1 antibodies failed to work on sections despite repeated trials. To study the possible relationship between migrating GnRH neurons and Npn-2, we performed double immunofluorescence experiments using contiguous sections. Fresh-frozen $15 \mu \mathrm{m}$ sections of E15 mouse heads were prepared and incubated contiguously with monoclonal pe-

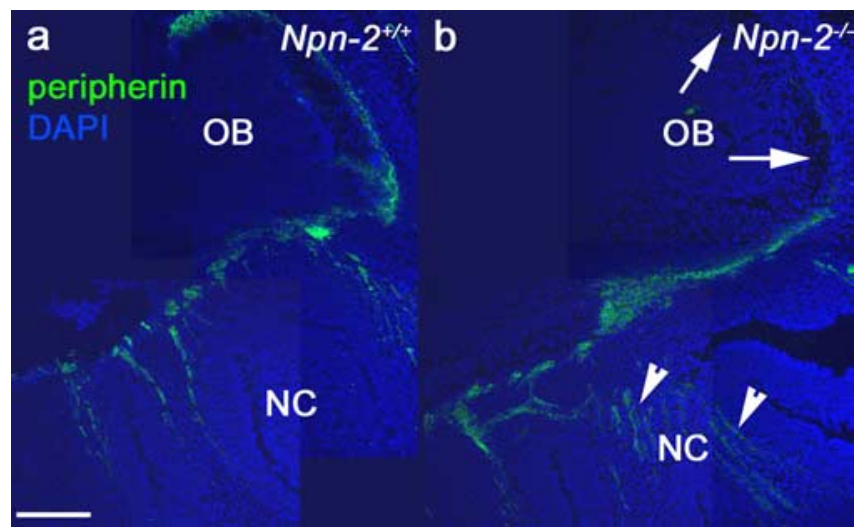

Figure 2. Innervation of the olfactory bulb by peripherin-positive olfactory fibers. $\boldsymbol{a}, \boldsymbol{b}, \mathrm{Sag}$ ittal sections through the nasal regions and the rostral forebrain at $\mathrm{E} 15$ showed defasciculation of the fibers stained for peripherin (green) ( $\boldsymbol{b}$, arrowheads) in the nasal compartment $(\mathrm{NC})$ and improper innervation of the olfactory bulb (OB) $\left(\boldsymbol{b}\right.$, arrows) of $\mathrm{Npn}^{-2^{-1-}}$ mice compared with Npn-2 $2^{+/+}(\boldsymbol{a})$. Scale bar, $100 \mu \mathrm{m}$. 
a 1. Dissection of olfactory regions from GFP-GnRH mice
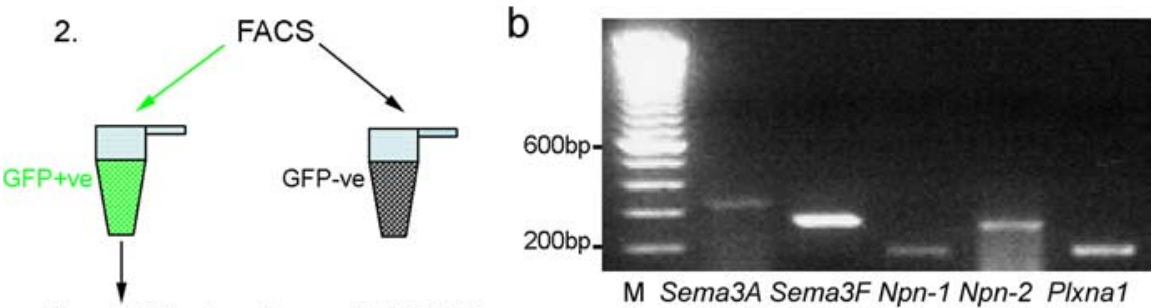

3. mRNA extraction and RT-PCR

M Sema3A Sema3F Npn-1 Npn-2 Plxna1
C
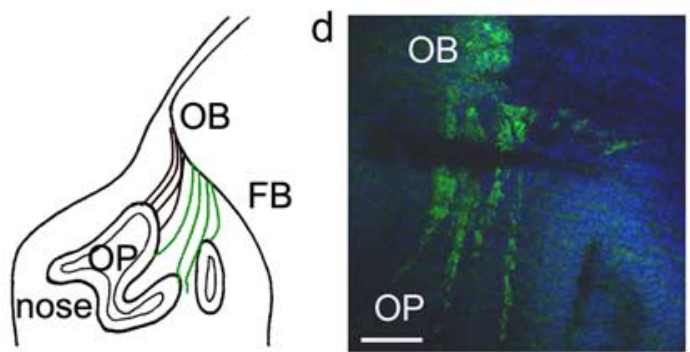

e
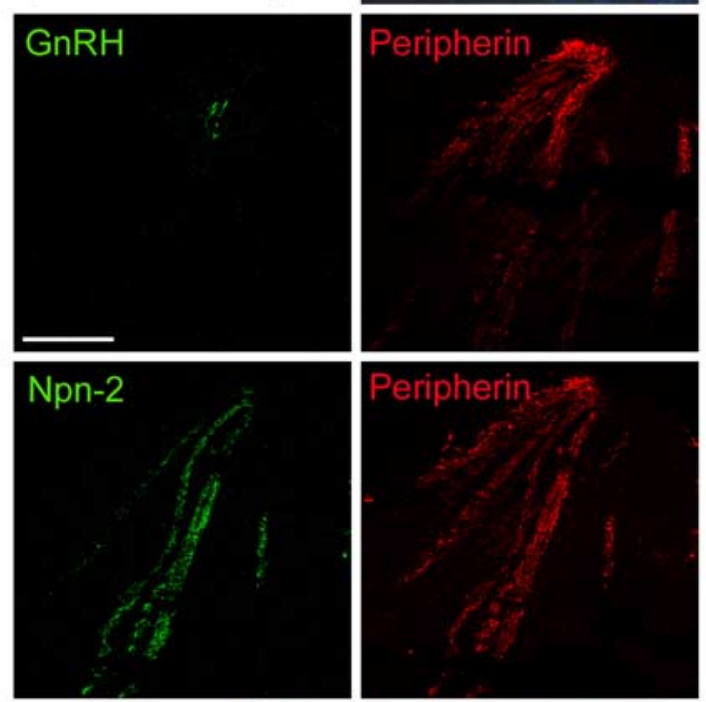

f
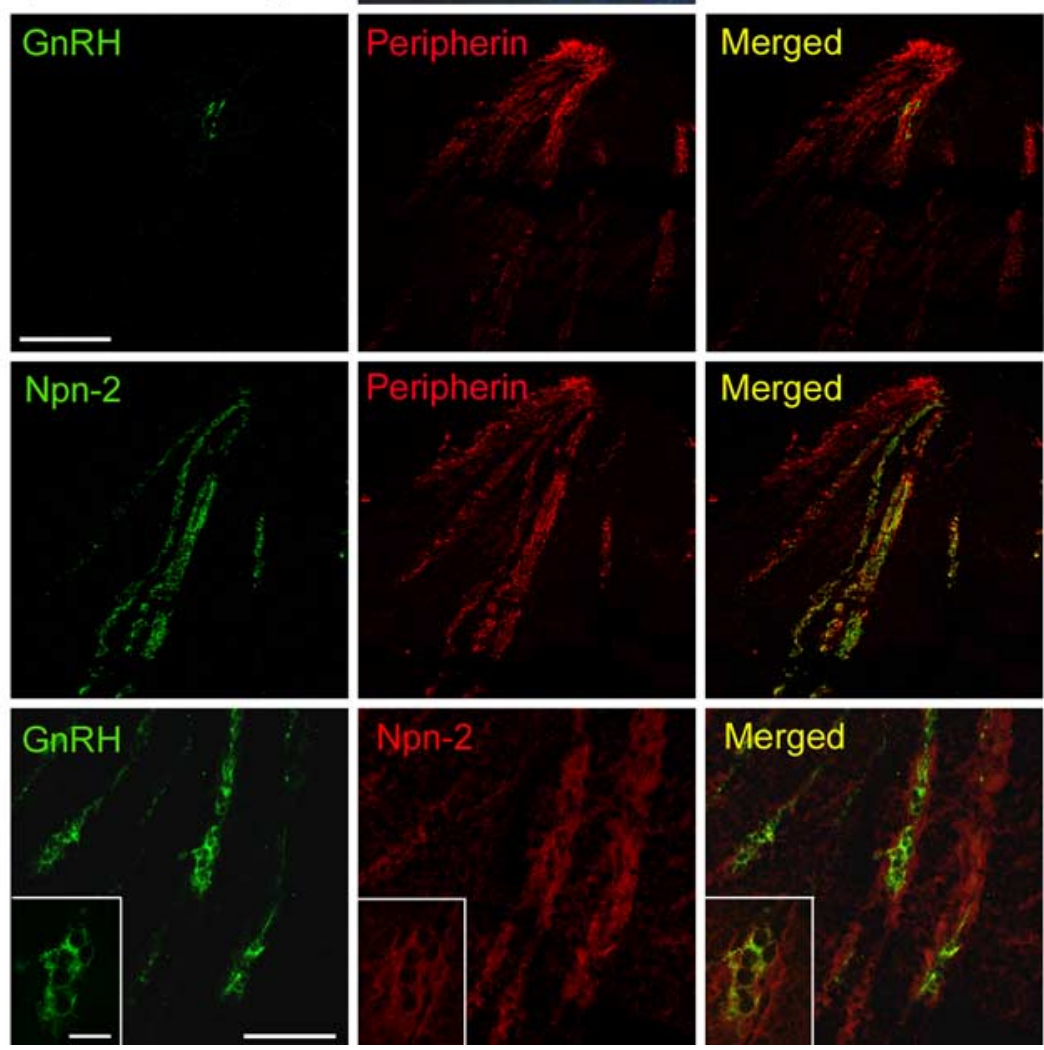

Figure 3. Expression of semaphorin and neuropilin molecules in GnRH neurons. $\boldsymbol{a}$, Schematic drawing of the experimental paradigm used to isolate mRNA from GFP-GnRH neurons. Fluorescence-activated cell sorting was applied to cells dissected from GFP-GnRH mice at different embryonic stages; mRNA extraction and RT-PCR were performed on GFP-positive samples. $\boldsymbol{b}, \mathrm{RT}$-PCR analysis at E13, using GFP-GnRH cell mRNA, showed the presence of Sema3A, Sema3F, Npn-1, Npn-2, and Plxna1 transcripts (330, $262,190,260$, and $199 \mathrm{bp}$, respectively). c, Schematic drawing of the anatomy of the olfactory system in embryonic rodents. Olfactory fibers originating from the olfactory placode (OP) are depicted as black and green lines. The latter correspond to the VNNs, specifically labeled for Npn-2. GnRH neurons are typically seen in association with these bundles of fibers. $\boldsymbol{d}$, Immunofluorescence, applied to sagittal sections taken from E15 mouse, showing Npn-2-immunoreactive olfactory fibers (green) originating from the OP. Nuclei were counterstained with DAPI (blue). e, Multipanel composition of contiguous sections taken from the nose of an $\mathrm{E} 15$ mouse and stained for GnRH and Npn-2 (green) and peripherin (red). As shown in the merged panels resulting from the overlays between $\mathrm{GnRH} / \mathrm{Npn}-2$ and $\mathrm{GnRH} /$ peripherin staining, GnRH neurons are in close association with peripherin-positive fibers, which are specifically stained also for Npn-2.f, Double immunofluorescence for GnRH (green) and Npn-2 (red) on sagittal sections taken from E13.5 mouse showing colocalization of the two antigens in the same cells, shown in the small inset, derived from single high-magnification confocal scans. FB, Forebrain; + ve, positive; -ve, negative; M, marker. Scale bars: $\boldsymbol{d}, 100 \mu \mathrm{m} ; \boldsymbol{e}$, $250 \mu \mathrm{m} ; \boldsymbol{f}, 100 \mu \mathrm{m} ; \boldsymbol{f}$, inset, $50 \mu \mathrm{m}$. ripherin antibody, a specific marker of the olfactory nerves, and polyclonal GnRH or Npn-2 antibodies. As illustrated in Figure $3 e, \mathrm{GnRH}$ cells (green) in the nasal region were in close association with peripherinpositive fibers (red); the contiguous sections stained for peripherin and Npn-2 showed that a subset of these peripherin fibers were also Npn-2 positive. These experiments showed the association of GnRH neurons with Npn-2-positive fibers, suggesting a role for neuropilins and their ligands in the migration of these cells and the possibility of a mutual influence between the olfactory and GnRH neuronal systems. Moreover, using a protocol for immunostaining with two antibodies raised in the same species, we found clear evidence of colocalization of GnRH and Npn-2 in the nasal compartments of E13 mice (Fig. $3 f$ ).

\section{Semaphorins and neuropilins are involved in the migration of immortalized GnRH neurons}

We tested the possible effects of semaphorins and neuropilins on the migration of GnRH neurons by using a model of immortalized GnRH cells (GN11 cell line). GN11 cells show a strong chemomigratory response in vitro (Maggi et al., 2000) and, as such, they have been used to investigate mechanisms involved in GnRH neuron migration (Giacobini et al., 2002; Cariboni et al., 2004, 2005). We first performed expression studies on GN11 cells to confirm our in vivo observations. Using RT-PCR and the same set of primers used for the analysis of GFP-GnRH neurons, we found an identical pattern of expression for mouse Sema3A, Sema3F, Npn-1, Npn-2, and Plxnal in these cells (Fig. 4a). Nested PCR with a second set of primers confirmed the specificity of the firstround reaction (data not shown). Moreover, immunofluorescence experiments with receptor-specific antibodies revealed the presence of Npn-1, Npn-2, and Plxna1 in GN11 cells, showing similar cytoplasmic vesicular expression as well as distribution at the surface membrane for all three receptor proteins (Fig. 4c,e,f). In these experiments, we observed stronger immunoreactivity of GN11 for Npn-2 compared with Npn-1, suggesting the possible predominance of expression of this receptor protein in $\mathrm{GnRH}$ neurons in vivo. In addition, we found that Sema3A and Sema3F could induce internalization of Npn-1 and Npn-2, respectively (Fig. $4 d, g$ ). Specifically, Npn-1 and Npn-2 formed immunopositive aggregates within the cytoplasm after stimulation 
with CM-Sema3A and -Sema3F for 60 min. Previous studies in COS-7 (Castellani et al., 2004) and endothelial cells (Narazaki and Tosato, 2006) have demonstrated that Sema3A can induce Npn-1 internalization; here, we demonstrate that this event can also occur in neuronal cells and, in addition, that Sema3F can induce Npn-2 internalization, possibly by downregulating the receptor itself. Together, these data indicate that GN11 cells may be used as a model system to study the biological effects of neuropilins and semaphorins and their roles in the migration of GnRH neurons.

\section{The effects of semaphorins and VEGFs} on the migration of GnRH neurons

We then performed chemomigration studies, taking advantage of the migratory properties of this cell line. We first tested the roles of Sema3A and Sema3F, because they represent the classical ligands of neuropilins and are expressed in the nasal region (Cloutier et al., 2002). As a source of semaphorins, we used CM of COS-7 cells transfected with Sema3A and Sema3F expression vectors (see Materials and Methods). We used aggregates of GN11 cells in a three-dimensional collagen gel as previously described (Cariboni et al., 2005). These aggregates were treated with either $1 \%$ FBS (positive control) or CM from untransfected or semaphorin $(3 \mathrm{~A}, 3 \mathrm{~F})$ transfected COS cells. Any displacement of cells from the aggregates was observed and documented for each treatment. As illustrated in representative samples (Fig. $5 a$ ), numerous GN11 cells appeared to move away from aggregates maintained in 1\% FBS or control CM (CM-COS) for $24 \mathrm{~h}$ (first and second top panels), but not from aggregates exposed to Sema3A- and Sema3F-enriched media (third and fourth bottom panels). These observations suggested an inhibitory role for Sema3A and Sema3F on the migration of GnRH neurons.

To confirm the repulsive activity of Sema3A and Sema3F on the migration of GN11 cells, we performed chemomigration assays using a 48-well Boyden's chamber, a method that has been shown to provide a sensitive and quantitative measure of cellular responses to specific chemotropic signals. GN11 cells were exposed for $3 \mathrm{~h}$ to a concentration gradient (chemotaxis) of CM of COS cells transfected with Sema3A and Sema3F vectors and with corresponding mock vectors (see Materials and Methods). We found that the chemomigration of GN11 cells was significantly diminished in the presence of both semaphorins compared with control media, with greater reduction in the number of migrating cells toward Sema3F, which is the primary ligand of Npn-2 (Fig. $5 b$ ). To confirm that the effects observed were specifically attributable to the semaphorins secreted by transfected cells, we attempted to neutralize Sema3A and Sema3F by preincubating the $\mathrm{CM}$ with anti-c-myc and anti-FLAG antibodies, respectively. Figure $5 c$ shows that immunoneutralization of semaphorins significantly restored the chemomigration of GN11 cells induced by
Sema3A and Sema3F, whereas the presence of the antibodies did not affect the response elicited by control CM on GN11 cells. These results clearly show the specificity of the biological effects observed and exclude any possibility of methodological artifacts. Moreover, these results prompted us to hypothesize a direct role of semaphorins on the migration of GnRH neurons.

However, because both neuropilins can also bind certain forms of VEGF (Soker et al., 1998; Gluzman-Poltorak et al., 2000, 2001; Karpanen et al., 2006), we asked whether these molecules modulate the effects observed and play a role on the migration of GnRH neurons. In particular, because both Npn-1 and Npn-2 can bind VEGF ${ }^{165}$, and Npn-2 also binds VEGF-C (Neufeld et al., 2002), we focused our experiments on these two forms. Thus, we exposed GN11 cells to different concentrations of mouse VEGF $^{165}$ and VEGF-C alone or in combination and found that both molecules induce significant migration of GN11 cells compared with control medium, with a greater increase when added in combination (data not shown). Moreover, we analyzed the effects of simultaneous exposure of GN11 to semaphorins and VEGFs and observed that the addition of VEGF ${ }^{165}$ and VEGF-C to the CM-Sema3A and CM-Sema3F reversed the inhibitory effects of semaphorins themselves (Fig. $5 d$ ). Together, these observations indicate that, at least in vitro, neuropilins function simultaneously as VEGF and semaphorin receptors, and suggest the possibility that the 
a
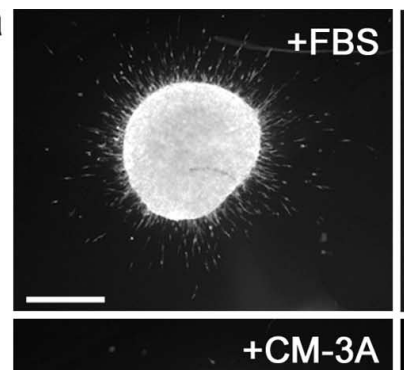

$+\mathrm{CM}-3 \mathrm{~A}$
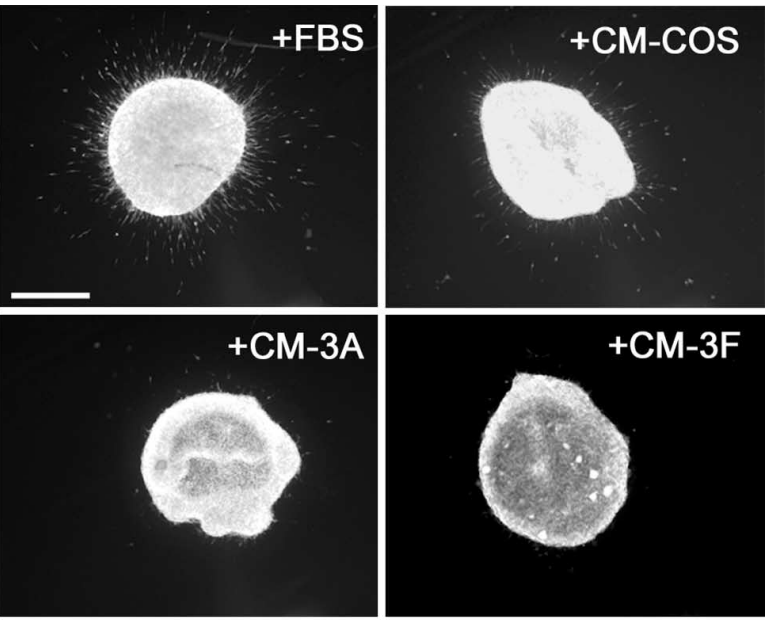

b

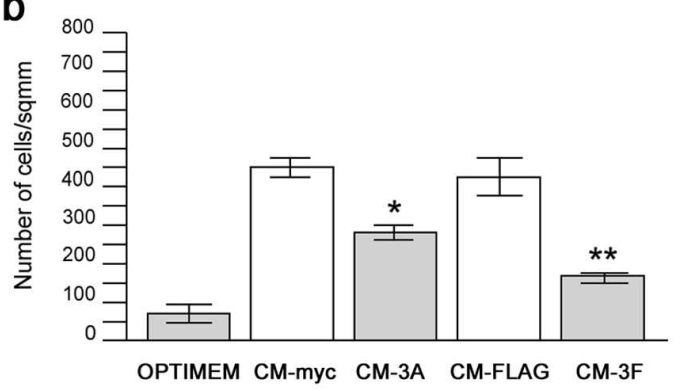

C

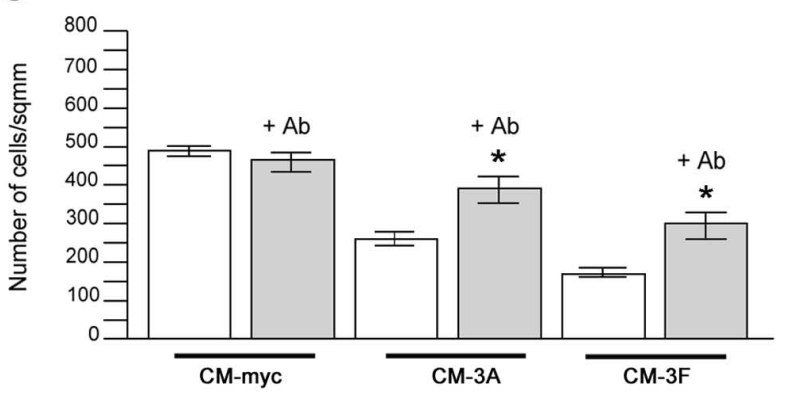

d

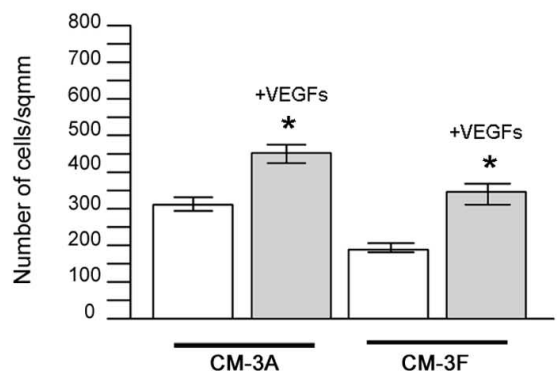

Figure 5. Effects of neuropilin ligands on migration of GN11. $\boldsymbol{a}$, Migration of GN11 cells was inhibited by Sema3A and Sema3F in three-dimensional collagen matrices. GN11 cells moved away from the aggregate in the presence of $1 \% \mathrm{FBS}$ (positive control) and CM-COS but not in the presence of CM-Sema3A and -Sema3F. Scale bar, $250 \mu \mathrm{m}$. $\boldsymbol{b}$, In a chemotactic assay, using a 48-well Boyden's chamber, CM-Sema3A and -Sema3F induced a significant reduction ( $p<$ 0.05 and 0.01 , respectively) of cells that migrated compared with control CM (CM-myc and CM-FLAG respectively). OptiMEM was a negative control (first column). c, Immunoneutralization of CM-Sema3A and -Sema3F with anti-c-myc and anti-FLAG antibodies significantly restored the number of cells that migrated, whereas it did not affect migration induced by control CMs, suggesting specificity of the effects observed. $\boldsymbol{d}$, Simultaneous exposure of GN11 cells to CM-Semas and VEGFs (+VEGFs) induced a reversal in the inhibitory effects of semaphorins, suggesting antagonistic effects of VEGFs on the migration of GN11 cells. ${ }^{*} p<0.05 ;{ }^{* *} p<0.01$. Error bars represent SEM. Ab, Antibody; CM-3A, CM-Sema3A; CM-3F, CM-Sema3F; sqmm, mm². migration of the GnRH neurons might be influenced by a balance between positive (VEGFs) and negative (semaphorins) cues, acting through common receptors (neuropilins).

\section{Discussion}

The GnRH-secreting neurons form the final component for the central regulation of reproduction by projecting to the median eminence. They originate in the nasal compartment $(\sim \mathrm{E} 10$ in mice) and associate with olfactory/vomeronasal nerves to migrate across the nasal septum and pass through the cribriform plate (between E12.5 and E15) (for review, see Tobet and Schwarting, 2006). Once within the forebrain, migrating $\mathrm{GnRH}$ neurons maintain their association with the caudal branch of the VNNs and attain their positions in the hypothalamus by the time of birth in rodents (Yoshida et al., 1995).

The factors that regulate the migration of GnRH neurons remain essentially unknown. Neuropilins and their ligands, semaphorins, are known to regulate axonal pathfinding and neuronal migration (for review, see $\mathrm{He}$ et al., 2002). Neuropilin-semaphorin interactions are important in the developing olfactory system, with widespread expression of Sema3A and Sema3F, Npn-1 and -2, and plexin-A1 documented throughout the system (Giger et al., 1996, 2000; Murakami et al., 2001; Cloutier et al., 2002). Interestingly, it has been shown that mice deficient for the Npn-2 gene show severe defasciculation of the VNNs and are frequently unable to reproduce (Giger et al., 2000; Walz et al., 2002).

Analysis of $\mathrm{Npn}-2^{-/-}$mice

We investigated the nature of this defect and found a significant reduction in the number of $\mathrm{GnRH}$ neurons in the hypothalamus of all Npn-2 $2^{-1-}$ mice. Furthermore, we found a comparable decrease in the size of their gonads as well as abnormal morphology of the seminiferous tubules without hyperplasia of Leydig's cells. This is in concordance with the reported hypogonadal phenotype of mice that carry an intragenic deletion in the GnRH gene (Cattanach et al., 1977; Mason et al., 1986). We then observed an abnormal increase of GnRH neurons clustered in the nose of newborn mice, indicating that many of these cells failed to migrate into the forebrain of $N p n-2^{-/-}$. This defect may be explained by the observed defasciculation of the VNNs in these animals (Giger et al., 2000) (Fig. 2). However, because neuropilin-semaphorin interactions are also involved in neuronal migration, as has been reported for cortical interneurons (Marin et al., 2001; Tamamaki et al., 2003) and neural crest cells (Yu and Moens, 2005), we asked whether the reduction in GnRH neurons observed in Npn-2 $2^{-/-}$mice was directly attributable to the action of these molecules in this system or secondary to the alteration of the axonal scaffold used in their migration.

\section{Semaphorins and their receptors in GnRH neurons}

To address this point, we took advantage of a line of transgenic mice in which GFP was genetically targeted to GnRH neurons (Suter et al., 2000). In these mice, nearly all GFP-expressing neurons contain immunologically detectable GnRH peptide. Using a novel approach of FACS analysis, we isolated GFP-positive cells from the heads of mice at three embryonic stages of GnRH neuron development and extracted mRNA. RT-PCR analysis showed that GFP-positive neurons expressed specific transcripts for Npn-1, Npn-2, plexin-A1, and the respective ligands, Sema3A and Sema3F, at all three embryonic stages. These experiments support a role for neuropilin/semaphorin in the development of the GnRH neuroendocrine system. They also indicate possible 
paracrine as well as cell-autonomous modes of action of these molecules, because ligand and receptor/coreceptor transcripts were found in the same cells. This is in accordance with other studies that showed that some migrating cells and axons express both receptors and ligands (Winberg et al., 1998) or secrete semaphorins in an autocrine manner (Serini et al., 2003; Catalano et al., 2004).

We also performed expression studies using a doubleimmunofluorescence protocol and visualized GnRH neurons in close association with bundles of VNNs axons expressing Npn-2, suggesting a preference for these neurons for subsets of fibers and supporting the importance of neuropilin in this system. Moreover, we found colocalization of GnRH and Npn-2 in GnRHsecreting neurons migrating along olfactory fibers, highlighting the importance of Npn-2 for both neurons and fibers. The expression of Npn-2 along olfactory axons has been described previously (Giger et al., 2000), but never linked to the migration of GnRH neurons. Our results indicate that lack of Npn-2, normally expressed in subsets of olfactory axons and GnRH neurons, may underlie navigation errors of such neurons, possibly because of deficient signaling between neuropilins and their ligands within the nasal compartment.

Role of neuropilin ligands in the migration of GnRH neurons Functional studies of GnRH-secreting neurons have been hindered by their peculiar anatomical distribution. However, investigations have been facilitated by the availability of immortalized mouse GnRH-expressing neurons (GN11 cells) (Radovick et al., 1991). These cells show strong chemomigratory activity in vitro (Maggi et al., 2000) and have been used to study mechanisms involved in $\mathrm{GnRH}$ neuron migration (Giacobini et al., 2002; Cariboni et al., 2004, 2005).

Using RT-PCR, we first confirmed that GN11 cells express semaphorins and their receptors similar to GFP-GnRH neurons, demonstrating that this cell line retains many of the features of $\mathrm{GnRH}$ neurons in vivo. Moreover, using immunofluorescence, we noticed the predominant expression of Npn-2 protein, supporting the importance of this neuropilin and its ligand, Sema3F, in this system. We then used collagen gel assays and observed that the migration of GN11 cells is inhibited by the exposure to Sema3A- and Sema3F-enriched media. We used a Boyden's chamber assay to quantify these results and to verify the specificity of the observed effect. In these experiments, we found that exposure of GN11 cells to a gradient of concentration of Sema3A and Sema3F strongly inhibited their migration, with the action of the latter being more pronounced. This effect was specifically blocked by the addition of antibodies directed to the tag epitopes at the $\mathrm{N}$ terminus of semaphorins and, surprisingly, was reversed by the addition of VEGF ${ }^{165}$ and VEGF-C, another class of molecules able to bind both Npn-1 and Npn-2 (Soker et al., 1998; Gluzman-Poltorak et al., 2000, 2001; Karpanen et al., 2006). These results demonstrate, first, a direct role for neuropilin ligands on the migration of GnRH neurons, at least in vitro; and, again, confirm a major role for Npn-2. Second, they suggest a likely mechanism of action of these molecules in vivo, possibly involving a complex balance between negative (semaphorins) and positive (VEGFs) cues acting through common receptors (neuropilins).

The mechanisms by which neuropilins switch between semaphorin and VEGF signaling are still unclear. However, the existence of antagonistic effects of semaphorins and VEGFs on migration events has already been demonstrated in neural progenitors cells (Bagnard et al., 2001) and, very recently, in human endothelial cells (Favier et al., 2006). Furthermore, it cannot be excluded that in vivo Sema3A and Sema3F could act as positive and negative signals at the same time, depending on their concentration and on the presence of other competitive factors or other semaphorins (e.g., Sema3B, Sema3C, or Sema3D), not tested in this study. This is in accordance with reports showing that semaphorins are not only inhibitory factors, but sometimes can promote cell chemotaxis and attraction of cell processes ( $\mathrm{Pol}-$ leux et al., 2000; Giordano et al., 2002; Moreno-Flores et al., 2003; Pasterkamp et al., 2003). These opposing responses might entail signaling pathways that are mediated by different semaphorin receptor complexes. The contrasting actions of semaphorins and VEGFs on GN11 cell migration could also support the autocrine effects proposed and raise the possibility of signaling between $\mathrm{GnRH}$ neurons themselves. Moreover, the finding of an effect of VEGFs on the migration of GnRH neurons opens the possibility of communication between the vascular and this neuroendocrine system. It has been reported that the appearance of olfactory axons coincides with the onset of vasculogenesis in the nasal mesenchyme and precedes the initial detection of GnRH immunoreactivity in the olfactory placode (Schwanzel-Fukuda, 1999). According to this evidence, it is possible that migratory signals directed to GnRH neurons might arise from nasal mesenchyme and from the concomitant vasculogenesis.

In conclusion, we have presented evidence for a primary role of neuropilins and their ligands in the migration of GnRH neurons and proposed a complex mechanism of action of these molecules. In particular, we have documented the importance of Npn-2 in this system: mice lacking this neuropilin show a markedly reduced number of GnRH neurons in the hypothalamus and reduction in gonadal size, which is likely the cause of their reported reduced fertility. More generally, these findings provide new insights into the molecular mechanisms of GnRH-migrating neurons and suggest new candidate genes that are likely to be involved in the pathogenesis of hypogonadotropic hypogonadisms in humans.

\section{References}

Bagnard D, Vaillant C, Khuth ST, Dufay N, Lohrum M, Puschel AW, Belin MF, Bolz J, Thomasset N (2001) Semaphorin 3A-vascular endothelial growth factor-165 balance mediates migration and apoptosis of neural progenitor cells by the recruitment of shared receptor. J Neurosci 21:3332-3341.

Barry J, Hoffman GE, Wray S (1985) LHRH-containing systems. In: Handbook of chemical neuroanatomy, Vol 4, Pt I (Björklund A, Hökfelt T, eds), pp 166-215. Amsterdam: Elsevier.

Cariboni A, Pimpinelli F, Colamarino S, Zaninetti R, Piccolella M, Rumio C, Piva F, Rugarli EI, Maggi R (2004) The product of X-linked Kallmann's syndrome gene (KAL1) affects the migratory activity of gonadotropinreleasing hormone (GnRH)-producing neurons. Hum Mol Genet 13:2781-2791.

Cariboni A, Rakic S, Liapi A, Maggi R, Goffinet A, Parnavelas JG (2005) Reelin provides an inhibitory signal in the migration of gonadotropinreleasing hormone neurons. Development 132:4709-4718.

Castellani V, Falk J, Rougon G (2004) Semaphorin3A-induced receptor endocytosis during axon guidance responses is mediated by L1 CAM. Mol Cell Neurosci 26:89-100.

Catalano A, Caprari P, Rodilossi S, Betta P, Castellucci M, Casazza A, Tamagnone L, Procopio A (2004) Cross-talk between vascular endothelial growth factor and semaphorin-3A pathway in the regulation of normal and malignant mesothelial cell proliferation. FASEB J 18:358-360.

Cattanach BM, Iddon CA, Charlton HM, Chiappa SA, Fink G (1977) Gonadotrophin-releasing hormone deficiency in a mutant mouse with hypogonadism. Nature 269:338-340.

Cloutier JF, Giger RJ, Koentges G, Dulac C, Kolodkin AL, Ginty DD (2002) Neuropilin-2 mediates axonal fasciculation, zonal segregation, but not axonal convergence, of primary accessory olfactory neurons. Neuron 33:877-892. 
Cloutier JF, Sahay A, Chang EC, Tessier-Lavigne M, Dulac C, Kolodkin AL, Ginty DD (2004) Differential requirements for semaphorin $3 \mathrm{~F}$ and Slit-1 in axonal targeting, fasciculation, and segregation of olfactory sensory neuron projections. J Neurosci 24:9087-9096.

Favier B, Alam A, Barron P, Bonnin J, Laboudie P, Fons P, Mandron M, Herault JP Neufeld G, Savi P, Herbert JM, Bono F (2006) Neuropilin-2 interacts with VEGFR-2 and VEGFR-3 and promotes human endothelial cells survival and migration. Blood 108:1243-1250.

Giacobini P, Giampietro C, Fioretto M, Maggi R, Cariboni A, Perroteau I, Fasolo A (2002) Hepatocyte growth factor/scatter factor facilitates migration of GN-11 immortalized LHRH neurons. Endocrinology 143:3306-3315.

Giacobini P, Kopin AS, Beart PM, Mercer LD, Fasolo A, Wray S (2004) Cholecystokinin modulates migration of gonadotropin-releasing hormone-1 neurons. J Neurosci 24:4737-4748.

Giger RJ, Wolfer DP, De Wit GM, Verhaagen J (1996) Anatomy of rat semaphorin III/collapsin-1 mRNA expression and relationship to developing nerve tracts during neuroembryogenesis. J Comp Neurol 375:378-392.

Giger RJ, Cloutier JF, Sahay A, Prinjha RK, Levengood DV, Moore SE, Pickering S, Simmons D, Rastan S, Walsh FS, Kolodkin AL, Ginty DD, Geppert M (2000) Neuropilin-2 is required in vivo for selective axon guidance responses to secreted semaphorins. Neuron 25:29-41.

Giordano S, Corso S, Conrotto P, Artigiani S, Gilestro G, Barberis D, Tamagnone L, Comoglio PM (2002) The semaphorin 4D receptor controls invasive growth by coupling with Met. Nat Cell Biol 4:720-724.

Gluzman-Poltorak Z, Cohen T, Herzog Y, Neufeld G (2000) Neuropilin-2 is a receptor for the vascular endothelial growth factor (VEGF) forms VEGF-145 and VEGF-165. J Biol Chem 275:18040-18045.

Gluzman-Poltorak Z, Cohen T, Shibuya M, Neufeld G (2001) Vascular endothelial growth factor receptor-1 and neuropilin-2 form complexes. J Biol Chem 276:18688-18694.

Guthrie S, Lumsden A (1994) Collagen gel coculture of neural tissue. Neuroprotocols 4:116-120.

Hardelin JP (2001) Kallmann syndrome: towards molecular pathogenesis. Mol Cell Endocrinol 179:75-81.

He Z, Wang KC, Koprivica V, Ming G, Song HJ (2002) Knowing how to navigate: mechanisms of semaphorin signaling in the nervous system. Sci STKE 2002:RE1.

Karpanen T, Heckman CA, Keskitalo S, Jeltsch M, Ollila H, Neufeld G, Tamagnone L, Alitalo K (2006) Functional interaction of VEGF-C and VEGF-D with neuropilin receptors. FASEB J 20:1462-1472.

Kennedy TE, Serafini T, De la Torre JR, Tessier-Lavigne M (1994) Netrins are diffusible chemotropic factors for commissural axons in the embryonic spinal cord. Cell 78:425-435.

Kolodkin AL, Levengood DV, Rowe EG, Tai YT, Giger RJ, Ginty DD (1997) Neuropilin is a semaphorin III receptor. Cell 90:753-762.

Kruger RP, Aurandt J, Guan KL (2005) Semaphorins command cells to move. Nat Rev Mol Cell Biol 6:789-800.

MacColl G, Bouloux P, Quinton R (2002) Kallmann syndrome: adhesion, afferents, and anosmia. Neuron 34:675-678.

Maggi R, Pimpinelli F, Molteni L, Milani M, Martini L, Piva F (2000) Immortalized luteinizing hormone-releasing hormone neurons show a different migratory activity in vitro. Endocrinology 141:2105-2112.

Marin O, Yaron A, Bagri A, Tessier-Lavigne M, Rubenstein JL (2001) Sorting of striatal and cortical interneurons regulated by semaphorinneuropilin interactions. Science 293:872-875.

Mason AJ, Pitts SL, Nikolics K, Szonyi E, Wilcox JN, Seeburg PH, Stewart TA (1986) The hypogonadal mouse: reproductive functions restored by gene therapy. Science 234:1372-1378.

Merchenthaler I, Gorcs T, Setalo G, Petrusz P, Flerko B (1984) Gonadotropin-releasing hormone (GnRH) neurons and pathways in the rat brain. Cell Tissue Res 237:15-29.

Moreno-Flores MT, Martin-Aparicio E, Martin-Bermejo MJ, Agudo M, McMahon S, Avila J, Diaz-Nido J, Wandosell F (2003) Semaphorin 3C preserves survival and induces neuritogenesis of cerebellar granule neurons in culture. J Neurochem 87:879-890.

Murakami Y, Suto F, Shimizu M, Shinoda T, Kameyama T, Fujisawa $\mathrm{H}$ (2001) Differential expression of plexin-A subfamily members in the mouse nervous system. Dev Dyn 220:246-258.

Narazaki M, Tosato G (2006) Ligand-induced internalization selects use of common receptor neuropilin-1 by VEGF165 and semaphorin3A. Blood 107:3892-3901.
Neufeld G, Cohen T, Shraga N, Lange T, Kessler O, Herzog Y (2002) The neuropilins: multifunctional semaphorins and VEGF receptors that modulate axon guidance and angiogenesis. Trends Cardiovasc Med 12:13-19.

Pasterkamp RJ, Peschon JJ, Spriggs MK, Kolodkin AL (2003) Semaphorin 7A promotes axon outgrowth through integrins and MAPKs. Nature 424:398-405.

Polleux F, Morrow T, Ghosh A (2000) Semaphorin 3A is a chemoattractant for cortical apical dendrites. Nature 404:567-573.

Radovick S, Wray S, Lee E, Nicols DK, Nakayama Y, Weintraub BD, Westphal H, Cutler Jr GB, Wondisford FE (1991) Migratory arrest of gonadotropin-releasing hormone neurons in transgenic mice. Proc Natl Acad Sci USA 88:3402-3406.

Schwanzel-Fukuda M (1999) Origin and migration of luteinizing hormonereleasing hormone neurons in mammals. Microsc Res Tech 44:2-10.

Schwanzel-Fukuda M, Pfaff DW (1989) Origin of luteinizing hormonereleasing hormone neurons. Nature 338:161-165.

Schwarting GA, Kostek C, Ahmad N, Dibble C, Pays L, Puschel AW (2000) Semaphorin $3 \mathrm{~A}$ is required for guidance of olfactory axons in mice. J Neurosci 20:7691-7697.

Schwarz Q, Gu C, Fujisawa H, Sabelko K, Gertsenstein M, Nagy A, Taniguchi M, Kolodkin AL, Ginty DD, Shima DT, Ruhrberg C (2004) Vascular endothelial growth factor controls neuronal migration and cooperates with Sema3A to pattern distinct compartments of the facial nerve. Genes Dev 18:2822-2834.

Serini G, Valdembri D, Zanivan S, Morterra G, Burkhardt C, Caccavari F, Zammataro L, Primo L, Tamagnone L, Logan M, Tessier-Lavigne M, Taniguchi M, Puschel AW, Bussolino F (2003) Class 3 semaphorins control vascular morphogenesis by inhibiting integrin function. Nature 424:391-397.

Soker S, Takashima S, Miao HQ, Neufeld G, Klagsbrun M (1998) Neuropilin-1 is expressed by endothelial and tumor cells as an isoformspecific receptor for vascular endothelial growth factor. Cell 92:735-745.

Suter KJ, Song WJ, Sampson TL, Wuarin JP, Saunders JT, Dudek FE, Moenter SM (2000) Genetic targeting of green fluorescent protein to gonadotropinreleasing hormone neurons: characterization of whole-cell electrophysiological properties and morphology. Endocrinology 141:412-419.

Takahashi T, Fournier A, Nakamura F, Wang LH, Murakami Y, Kalb RG, Fujisawa H, Strittmatter SM (1999) Plexin-neuropilin-1 complexes form functional semaphorin-3A receptors. Cell 99:59-69.

Tamagnone L, Comoglio PM (2004) To move or not to move? Semaphorin signalling in cell migration. EMBO Rep 5:356-361.

Tamagnone L, Artigiani S, Chen H, He Z, Ming GI, Song H, Chedotal A, Winberg ML, Goodman CS, Poo M, Tessier-Lavigne M, Comoglio PM (1999) Plexins are a large family of receptors for transmembrane, secreted, and GPI-anchored semaphorins in vertebrates. Cell 99:71-80.

Tamamaki N, Fujimori K, Nojyo Y, Kaneko T, Takauji R (2003) Evidence that Sema3A and Sema3F regulate the migration of GABAergic neurons in the developing neocortex. J Comp Neurol 455:238-248.

Taniguchi M, Nagao H, Takahashi YK, Yamaguchi M, Mitsui S, Yagi T, Mori K, Shimizu T (2003) Distorted odor maps in the olfactory bulb of semaphorin 3A-deficient mice. J Neurosci 23:1390-1397.

Tobet SA, Schwarting GA (2006) Minireview: recent progress in gonadotropin-releasing hormone neuronal migration. Endocrinology 147:1159-1165.

Yoshida K, Tobet SA, Crandall JE, Jimenez TP, Schwarting GA (1995) The migration of luteinizing hormone-releasing hormone neurons in the developing rat is associated with a transient, caudal projection of the vomeronasal nerve. J Neurosci 15:7769-7777.

Yu HH, Moens CB (2005) Semaphorin signaling guides cranial neural crest cell migration in zebrafish. Dev Biol 280:373-385.

Walz A, Rodriguez I, Mombaerts P (2002) Aberrant sensory innervation of the olfactory bulb in neuropilin-2 mutant mice. J Neurosci 22:4025-4035.

Winberg ML, Noordermeer JN, Tamagnone L, Comoglio PM, Spriggs MK, Tessier-Lavigne M, Goodman CS (1998) Plexin A is a neuronal semaphorin receptor that controls axon guidance. Cell 95:903-916.

Wray S (2001) Development of luteinizing hormone releasing hormone neurones. J Neuroendocrinol 13:3-11.

Wray S, Grant P, Gainer H (1989) Evidence that cells expressing luteinizing hormone-releasing hormone mRNA in the mouse are derived from progenitor cells in the olfactory placode. Proc Natl Acad Sci USA 86:81328136. 